\title{
Empirical Research on the Forecast of the Regional Logistics Demand Based on BP Neural Network Nonlinear Nombinatorial Model
}

\author{
Yingyi Huang ${ }^{1,2, ~ a, ~ W e i b i n ~ L i n ~}{ }^{1, b}$ * \\ ${ }^{1}$ TSL School of Busines, Quanzhou Normal University, Quanzhou 362000, China \\ ${ }^{2}$ The Cloud Computing \& Internet of Things \& Electronic Commerce University \\ Engineering Center in Fujian Province, Quanzhou 362000, China \\ ahuangyingyi31@163.com, ${ }^{b} 279815010 @ q q . c o m$
}

Keywords: BP neural network; nonlinear; logistics demand; forecast

\begin{abstract}
With the rapid development of economic globalization and informatization, rapid growth of logistics causes the imbalance between logistics supply and demand. Hence, it is critical to make the accurate logistics demand forecast for the sustainable and sound development of logistics. To achieve that, a nonlinear combinatorial model is constructed for the forecast of the regional logistics based on BP neural network. And the results show that this model with the relatively strong nonlinear mapping ability and comparatively accurate predictive effect provides decisions for logistics planning.
\end{abstract}

\section{Introduction}

With the speedy growth of economy and information technique, modern logistics industry develops rapidly all over the world. It is of vital necessity for the sustainable development of regional logistics to make quantitative predictions for the logistics demand scale and development trend, and to keep the relative balance between supply and demand of logistics service [1]. At present, there have existed certain researches on the forecast of regional logistics, but most of them are using single forecasting model or linear combination forecasting model, which have some limitations [2-7]. However, BP neural network prediction method has various advantages such as self learning, training and correction, multidimensional processing, etc, and is able to adopt nonlinear system analysis, which is convenient to determine combination weight of each prediction model from the quantitative aspect so that it enhances the accuracy of the forecast. Meanwhile, it has a high degree of fitting for influencing the forecast of nonlinear complex system. Accordingly, this paper is doing a prediction research on the regional logistics demand by constructing a nonlinear combinatorial model based on BP neural network. 


\section{Establishing the Index System of Regional Logistics Demand Forecast}

Combining the principles of selecting the index of logistics demand forecasting system, in this paper, we establish the index set of logistics demand forecasting system from two aspects - logistics demand index and regional economic index - in the following Table 1.

Table 1 Index set of logistics demand forecasting system

\begin{tabular}{|c|c|c|c|}
\hline Index Set & Types of Index & $\begin{array}{c}\text { Standard of } \\
\text { Classification }\end{array}$ & Index Setting \\
\hline \multirow{9}{*}{$\begin{array}{l}\text { Index of } \\
\text { Logistics } \\
\text { Demand }\end{array}$} & \multirow{4}{*}{$\begin{array}{l}\text { Index of } \\
\text { Logistics } \\
\text { Demand Scale }\end{array}$} & From freight scale & $\begin{array}{l}\text { Integrated freight volume,rotation volume of } \\
\text { freight transport }\end{array}$ \\
\hline & & From logistics costs & $\begin{array}{l}\text { Total social logistics costs, the proportion of } \\
\text { logistics costs in GDP }\end{array}$ \\
\hline & & $\begin{array}{l}\text { From fixed assets } \\
\text { investment } \\
\end{array}$ & Aggregate investment in logistics fixed assets \\
\hline & & \begin{tabular}{|l|}
$\begin{array}{l}\text { From industry } \\
\text { employees }\end{array}$ \\
\end{tabular} & $\begin{array}{l}\text { The proportion of employees in total } \\
\text { employment or in total population }\end{array}$ \\
\hline & \multirow{5}{*}{$\begin{array}{l}\text { Index of } \\
\text { Logistics } \\
\text { Demand } \\
\text { Structure }\end{array}$} & $\begin{array}{l}\text { From modes of } \\
\text { transport }\end{array}$ & $\begin{array}{l}\text { Highway freight volume,railway freight } \\
\text { volume,waterway freight volume,airway freight } \\
\text { volume,pipeline freight volume }\end{array}$ \\
\hline & & $\begin{array}{l}\text { From logistics demand } \\
\text { objects }\end{array}$ & Industrial products, articles for daily use \\
\hline & & $\begin{array}{l}\text { From logistics service } \\
\text { functions }\end{array}$ & $\begin{array}{l}\text { Freight volume,storage volume, delivery } \\
\text { volume,distribution processing } \\
\text { volume,loading,unloading and delivery volume }\end{array}$ \\
\hline & & $\begin{array}{l}\text { From logistics service } \\
\text { forms }\end{array}$ & $\begin{array}{l}\text { Total volume of self-running logistics,total } \\
\text { volume of outsourcing logistics }\end{array}$ \\
\hline & & $\begin{array}{l}\text { From logistics flow } \\
\text { direction }\end{array}$ & $\begin{array}{l}\text { Total volume of internal logistics,Total volume } \\
\text { of external logistics }\end{array}$ \\
\hline \multirow{4}{*}{$\begin{array}{c}\text { Economic } \\
\text { Index of } \\
\text { Logistics } \\
\text { Demand } \\
\text { Forecast }\end{array}$} & \multicolumn{2}{|c|}{ Index of Economic Scale } & $\begin{array}{l}\text { Gross domestic product,per capita gross } \\
\text { domestic product }\end{array}$ \\
\hline & \multicolumn{2}{|c|}{ Index of Industry Structure } & $\begin{array}{l}\text { Gross product of primary industry,gross } \\
\text { product of the second industry,gross product of } \\
\text { the third industry }\end{array}$ \\
\hline & \multicolumn{2}{|c|}{ Index of Domestic and Foreign Trade } & Gross retail sales,total foreign trade value \\
\hline & \multicolumn{2}{|c|}{ Index of Household Consumption Level } & Per capita income,per capita consumption level \\
\hline
\end{tabular}

Combining the analysis of the relative index selection above and considering the availability of statistical data and correlation between each two indexes, in this paper, we choose freight volume (Y ten thousand tons) as the measurement index for the regional logistics demand scale,and choose regional gross domestic product(GDP) X1 (one hundred million yuan),output value of primary industry X2 (one hundred million yuan), output value of the second industry X3 (one hundred million yuan), output value of the third industry X4 (one hundred million yuan),gross retail sales X5 (one hundred million yuan),total regional foreign trade value X6 (ten thousand yuan),per capita consumption level X7 (yuan),etc,as the economic indexes for forecasting the regional logistics demand scale.The specific index system is established in Table 2. 
Table 2 Index system for forecasting the regional logistics demand

\begin{tabular}{|l|c|}
\hline Index & \\
\hline Freight Volume & $\mathrm{Y}$ \\
\hline Regional Gross Domestic Product & $\mathrm{X} 1$ \\
\hline Output Value of Primary Industry & $\mathrm{X} 2$ \\
\hline Output Value of the Second Industry & $\mathrm{X} 3$ \\
\hline Output Value of the Third Industry & $\mathrm{X} 4$ \\
\hline Gross Retail Sales & $\mathrm{X} 5$ \\
\hline Total Regional Foreign Trade Value & $\mathrm{X} 6$ \\
\hline Per Capita Consumption Level & $\mathrm{X} 7$ \\
\hline
\end{tabular}

\section{Empirical Research}

The established forecasting index system will be applied to BP neural network, GM $(1,1)$ model, exponential smoothing model, regression analysis method and the paper's model by selecting Fujian province’s freight volume from 2006 to 2014 and relative economic influencing factors.

\subsection{Basic data}

Table 3 Freight and other economic influencing factors in Fujian province from 2006 to 2014

\begin{tabular}{|c|c|c|c|c|c|c|c|c|}
\hline Years & $\begin{array}{c}\text { Freight } \\
\text { Volume } \\
\text { Y }\end{array}$ & $\begin{array}{c}\text { Provincial } \\
\text { GDP } \\
\text { X1 }\end{array}$ & $\begin{array}{c}\text { Output } \\
\text { Value of } \\
\text { Primary } \\
\text { Industry }\end{array}$ & $\begin{array}{l}\text { Output } \\
\text { Value of } \\
\text { the Second } \\
\text { Industry }\end{array}$ & $\begin{array}{c}\text { Output } \\
\text { Value of } \\
\text { the Third } \\
\text { Industry }\end{array}$ & $\begin{array}{c}\text { Gross } \\
\text { Retail } \\
\text { Sales }\end{array}$ & $\begin{array}{c}\text { Total } \\
\text { Regional } \\
\text { Foreign } \\
\text { Trade Value }\end{array}$ & $\begin{array}{c}\text { Per Capita } \\
\text { Consumption } \\
\text { Level }\end{array}$ \\
\hline 2006 & 44304 & 7583.85 & 865.98 & 3695.04 & 3022.83 & 2717.62 & 49375457 & 7971 \\
\hline 2007 & 50500 & 9248.53 & 1002.11 & 4476.42 & 3770 & 3212.34 & 56612396 & 8943 \\
\hline 2008 & 57254 & 10823.01 & 1158.17 & 5318.44 & 4346.4 & 3866.69 & 58908991 & 10645 \\
\hline 2009 & 58231 & 12236.53 & 1182.74 & 6005.3 & 5048.49 & 4480.99 & 54408483 & 11336 \\
\hline 2010 & 66159 & 14737.12 & 1363.67 & 7522.83 & 5850.62 & 5310.03 & 73638807 & 13187 \\
\hline 2011 & 75272 & 17560.18 & 1612.24 & 9069.2 & 6878.74 & 6276.19 & 92698273 & 14958 \\
\hline 2012 & 84417 & 19701.78 & 1776.71 & 10187.94 & 7737.13 & 7256.53 & 98435836 & 16144 \\
\hline 2013 & 96718 & 21868.49 & 1936.31 & 11315.3 & 8508.03 & 8275.34 & 104864338 & 17115 \\
\hline 2014 & 111757 & 24055.76 & 2076.99 & 12501.06 & 9368.86 & 9346.7 & 17749.9171 & 18532 \\
\hline
\end{tabular}

\subsection{Comparative analysis}

In order to contrast the predictive effect of this nonlinear combinatorial model with the four single predictive methods, this paper uses the fitting value of each method and the absolute error and relative error between the actual values as the comparative standard. The fitting value error of five prediction methods is revealed in the Table 4. And the absolute and relative error of five prediction methods are as the following Table 5. 
Table 4 Analysis of freight volume fitting value in Fujian province

\begin{tabular}{|c|c|c|c|c|c|c|}
\hline \multirow{2}{*}{$\begin{array}{c}\text { Year } \\
\mathrm{s}\end{array}$} & \multirow{2}{*}{$\begin{array}{l}\text { Actual } \\
\text { Value }\end{array}$} & \multicolumn{5}{|c|}{ Fitting Value } \\
\hline & & $\mathrm{GM}(1,1)$ & $\begin{array}{c}\text { BP Neural } \\
\text { Network }\end{array}$ & $\begin{array}{c}\text { Exponential } \\
\text { Smoothing }\end{array}$ & Regression & $\begin{array}{c}\text { Nonlinear } \\
\text { Combination }\end{array}$ \\
\hline 2006 & 44304 & - & 44252.68 & - & 39634.69 & 45371.13 \\
\hline 2007 & 50500 & 47777.85 & 50410.30 & 51739.20 & 47631.91 & 50492.82 \\
\hline 2008 & 57254 & 53731.74 & 57216.83 & 60587.52 & 55629.12 & 57287.22 \\
\hline 2009 & 58231 & 60427.58 & 58513.27 & 61975.58 & 63626.34 & 58464.33 \\
\hline 2010 & 66159 & 67957.82 & 65795.49 & 70363.22 & 71623.56 & 65630.73 \\
\hline 2011 & 75272 & 76426.46 & 75515.88 & 81127.33 & 79620.77 & 75223.89 \\
\hline 2012 & 84417 & 85950.43 & 84891.97 & 91715.66 & 87617.99 & 84801.67 \\
\hline 2013 & 96718 & 96661.23 & 96061.63 & 105543.48 & 95615.21 & 97110.53 \\
\hline 2014 & 111757 & $\begin{array}{c}108706.7 \\
7\end{array}$ & 106077.57 & 122625.56 & 103612.42 & 111173.70 \\
\hline
\end{tabular}

It is shown in the Table 4 and Table 5, the relative error of nonlinear combinatorial model, BP neural network, GM(1,1),exponential smoothing model, regression analysis model is $0.07 \%, 0.58 \%, 1.0150 \%, 1.52 \%$ and $1.98 \%$ respectively, and the forecasting performance is from good to bad. Among those methods, BP neural network nonlinear combinatorial model established in this paper is able to guarantee the fine fitting value of the predictive model and actual data and the high accuracy, enabling to show more advantages of BP neural network in the actual use. In conclusion, comparing with other 4 single predictive models, the model proposed in this paper is more reasonable.

Hence, the whole province's freight volume in the five years is predicted,according to nonlinear combinatorial model: $x^{\prime} \quad(2015)=122755.67, x^{\prime} \quad(2016)=135392.87, x^{\prime} \quad(2017)=148561.14, x^{\prime}$ $(2018)=162044.11, x^{\prime}(2019)=175598.56$.

Table 5 Three Scheme comparing

\begin{tabular}{|c|c|c|c|c|c|c|c|c|c|c|}
\hline & \multicolumn{9}{|c|}{ Absolute Error } & \multicolumn{5}{c|}{ Relative Error } \\
\hline & GM(1,1) & BP & $\begin{array}{l}\text { Exponential } \\
\text { Smoothing }\end{array}$ & Regression & Combination & GM(1,1) & BP & $\begin{array}{l}\text { Exponential } \\
\text { Smoothing }\end{array}$ & Regression & Combination \\
\hline 2006 & - & -51.3 & - & -4669.31 & - & - & $-0.12 \%$ & - & $-10.54 \%$ & - \\
\hline 2007 & -2722.2 & -89.7 & 1239.20 & -2868.09 & -7.18 & $-5.39 \%$ & $-0.18 \%$ & $2.46 \%$ & $-5.68 \%$ & $-0.01 \%$ \\
\hline 2008 & -3522.3 & -37.2 & 3333.52 & -1624.88 & 33.22 & $-6.15 \%$ & $-0.07 \%$ & $5.82 \%$ & $-2.84 \%$ & $0.06 \%$ \\
\hline 2009 & 2196.6 & 282.3 & 3744.58 & 5395.34 & 233.33 & $3.77 \%$ & $0.48 \%$ & $6.43 \%$ & $9.27 \%$ & $0.40 \%$ \\
\hline 2010 & 1798.8 & -363.5 & 4204.22 & 5464.56 & -528.27 & $2.72 \%$ & $-0.55 \%$ & $6.35 \%$ & $8.26 \%$ & $-0.80 \%$ \\
\hline 2011 & 1154.5 & 243.9 & 5855.33 & 4348.77 & -48.11 & $1.53 \%$ & $0.32 \%$ & $7.78 \%$ & $5.78 \%$ & $-0.06 \%$ \\
\hline 2012 & 1533.4 & 474.9 & 7298.66 & 3200.99 & 384.67 & $1.81 \%$ & $0.56 \%$ & $8.65 \%$ & $3.79 \%$ & $0.46 \%$ \\
\hline 2013 & -56.8 & -656.4 & 8825.48 & -1102.79 & 392.53 & $-0.06 \%$ & $-0.68 \%$ & $9.12 \%$ & $-1.14 \%$ & $0.41 \%$ \\
\hline 2014 & -3050.2 & -5679.4 & 10868.56 & -8144.58 & -583.30 & $-2.73 \%$ & $-5.08 \%$ & $9.73 \%$ & $-7.29 \%$ & $-0.52 \%$ \\
\hline mean & 721.55 & 636.8 & 1513.47 & 1423.77 & 73.81 & $1.02 \%$ & $0.58 \%$ & $1.52 \%$ & $1.98 \%$ & $0.07 \%$ \\
\hline
\end{tabular}

\section{Conclusion}

By using five prediction methods like BP neural network, GM ( 1,1$)$ model, exponential smoothing model, regression analysis method, nonlinear combinatorial model based on BP neural network to do a prediction research on the regional logistics demand scale and structure in Fujian province, the conclusion is obtained that, firstly, it is a available and accurate research method to 
predict the regional logistics demand by using the indexes of logistics demand and regional economy; secondly, establishing nonlinear combinatorial model which is applied to predict the regional logistics demand not only gets over the disadvantage of traditional single forecast methods, but it has the high accuracy.

\section{Acknowledgments}

This work is partially supported by the Natural Science Foundation of Fujian Province for Youths, China (grant No. 2017J05116), the Natural Science Foundation of Fujian Province, China (grant No. 2015J01286), the JK class project in Fujian Province Department of Education (grant No. JK2014037), the Education Research Project of Fujian Province for Young and Middle-aged Teacher (grant No. JAS150448). We deeply appreciate the organizations mentioned above.

\section{References}

[1] Y. Liu, Analysis of Logistics Demand Based on Gray Forecasting Model, Logistics Technology, 31(2012)59-61.

[2] M.J. Wang, Z. Zhang, Logistics Demand Forecasting Model Based on Pheromone Time Series Method, Journal of Longdong University, 5 (2014)13-15.

[3] X.J. Zhou, Z.Y. Jing, Empirical Analysis of Logistics Demand Forecasting of Hebei Based on Multi-linear Regression Model, Logistics Technology, 2(2013)270-272.

[4] W.J. Ma, J. Li, GM (1,1)-based Forecasting of Logistics Demand in Coastal Region of Hebei, Logistics Technology, 31(2012)92-93.

[5] S.Y. Chen, Y.C. Guo, Study on Forecasting of Logistics Demand of Anhui Based on BP Neural Network, Logistics Technology, 17 (2012)231-233.

[6] G.X. Li, G.E. Xia. A combination forecasting model for regional logistics demand, Statistics \& Decision, 15 (2014)85-87.

[7] H. Zhao, On Regional Logistics Demand Index System Construction, Logistics Science and Technology, 33(2010)59-60. 